DOI: https://doi.org/10.15688/jvolsu2.2018.1.1

UDC $81^{\prime} 42: 2$

Submitted: 11.12.2017

LBC 81.055 .51

Accepted: 07.02.2018

\title{
PROTO-TEXTUALITY AS THE CONSTRUCTIVE PRINCIPLE OF RELIGIOUS STYLE ${ }^{1}$
}

\author{
Tatyana V. Itskovich
}

Ural Federal University named after the First President of Russia B.N. Eltsin, Ekaterinburg, Russia

\begin{abstract}
To the present day, the linguistic description of the religious style is reduced to characterizing certain genres, such as preaching, prayer, message, hagiography. The choice of the constructive principle of religious style and the description of its ontological foundations have not yet been set as an objective scholarly study. The paper demonstrates how the idea of proto-textuality of religious style and, consequently, the protogenic conditioning of all modern religious genres are advanced. The idea of proto-textuality receives a communicative, pragmatic and categorical textual basis in this research. The constructive principle of religious functional style is determined by the peculiarities of religious consciousness and religious activity. The characterization of these ontological principles of dual world and salvation lies in the notion of the textual sphere embodied in the constructive principle of proto-textuality, which implies the obligatory support of each of the following religious texts relating to the religious prototype.

Any kind of communication in the religious sphere is genetically derived from the prototype of Holy Scripture and Sacred Tradition and relies on them. The proto-text of Holy Scripture is a closed semantic formation, initially exhausting the body of real texts. The persons described in the Holy Scriptures are subjects of the proto-text that act in a certain historical objective-sacred time and space. In the prototype, invariant genre models that correspond to the goals of participants in religious communication during a particular historical period are fixed, and the protagonists of prayer, sermons and lives are immanently given. Each proto-genre is a text invariant, the basic initial basis of the genre.

Proto-genres are further developed, transforming into a modern genre system of religious functional style. The genre peculiarity of the texts created in the sphere of religious communication is determined by the proximity to the prototype and the degree or level of its reflection in the text being created. As applied to the genre level, this ratio is expressed in the genetic connection of later texts with genre proto-text. These genre samples not only set the canon of the genre but are actively used in modern religious communication.

Thus, the ontological basis of a religious style is the dual reality, and salvation is the main intention of religious text-generation. Philosophical understanding of dual reality as a distinctive feature of religious consciousness is realized in religious style through proto-textuality. Proto-textuality is a constructive feature of the religious functional style, which determines the binding indissoluble bond of all genres-text-types with protogens. Thus, the continuity and safety of canonical ideological constructs are provided in protests in a concentrated form. The ideological and content proximity to the prototype, following the canons defined in it, determines the field $\infty$ structure of genres of religious style, their nuclear or peripheral affiliation.

ㄱ. Key words: style, religious functional style, constructive principle, proto-text, proto-textuality, world duality, stylistic features.

Citation. Itskovich T.V. Proto-Textuality as the Constructive Principle of Religious Style. Vestnik Volgogradskogo gosudarstvennogo universiteta. Seriya 2, Yazykoznanie [Science Journal of Volgograd State University. Linguistics], 2018, vol. 17, no. 1, pp. 6-16. (in Russian). DOI: https://doi.org/10.15688/jvolsu2.2018.1.1
\end{abstract}




\title{
ПРОТОТЕКСТУАЛЬНОСТЬ КАК КОНСТРУКТИВНЫЙ ПРИНЦИП РЕЛИГИОЗНОГО СТИЛЯ ${ }^{1}$
}

\author{
Татьяна Викторовна Ицкович \\ Уральский федеральный университет им. первого Президента России Б.Н. Ельцина, \\ г. Екатеринбург, Россия
}

\begin{abstract}
Аннотация. В России последних десятилетий XX в. парадигма функциональных стилей русского литературного языка дополняется религиозным стилем. Выделение конструктивного принципа религиозного стиля, описание его онтологических оснований до сих пор не становилось самостоятельной целью научного исследования. Конструктивный принцип религиозного функционального стиля обусловлен особенностями религиозного сознания и религиозной деятельности. Онтологические принципы двоемирия и спасения в проекции на текстосферу воплощаются в конструктивном принципе прототекстуальности, предполагающем обязательную для каждого из последующих религиозных текстов опору на религиозный прототекст. Под прототекстом понимается завершенный, закрытый канонический текст, передающий слова Бога или пророков и содержащий в концентрированном виде ценностно-смысловые установки определенной конфессии. В прототексте задаются установки и описываются образцы, которые формируют должное поведение человека. Прототекст является нерушимым идейным основанием и материально-языковым базисом всех производных текстов религиозного функционального стиля.

Конструктивный принцип прототекстуальности позволяет проецировать религиозное мировоззрение на текст. Каждый новый религиозный текст создается с прямой опорой на канонический образец (прототекст). Каждый современный религиозный жанр имеет канонический прототип. Современная жанровая система религиозного функционального стиля сформировалась на основе триады протожанров (молитва, проповедь, житие), реализованных в религиозном прототексте Священного Писания, ядро которого в христианстве составляет Евангелие. Каждый протожанр религиозного стиля развивается в современный жанровый тип со своим набором жанров и субжанров.

Ключевые слова: стиль, религиозный функциональный стиль, конструктивный принцип, прототекст, прототекстуальность, двоемирие, стилевые черты.
\end{abstract}

Цитирование. Ицкович Т.В. Прототекстуальность как конструктивный принцип религиозного стиля // Вестник Волгоградского государственного университета. Серия 2, Языкознание. - 2018. - Т. 17, № 1. - С. 6-16. DOI: https://doi.org/10.15688/jvolsu2.2018.1.1

\section{Религиозный стиль: параметры выделения}

В России последних десятилетий XX в. религия снова стала значимой сферой общественного сознания. Это привело к активизации внимания исследователей к религиозной коммуникации (см.: [Бобырева, 2013; Бугаева, 2016; Гадомский, 2009; Крылова, 2001; Крысин, 1996; Прохватилова, 1999; Салимовский, Суслова, 2005]). Одно из актуальных направлений в ее изучении связано с пониманием религиозного стиля как функционального стиля русского литературного языка.

Основания для его выделения, по сути являющиеся экстралингвистическими, были предложены в работах М.Н. Кожиной, которая определяет функциональный стиль речи как «своеобразный характер речи той или иной социальной ее разновидности, соответствующей определенной сфере общественной деятельности и соотносительной с ней форме сознания, создаваемый особенностями функционирования в этой сфере языковых средств и специфической речевой организацией, несущей определенную стилистическую окраску» [Кожина, 1977, с. 42].

В связи с этим нельзя не отметить парадоксальную ситуацию, существовавшую в отечественной лингвистике: такая сфера общественного сознания, как религия, в силу исторически сложившихся общественных отношений в России XX в. не характеризовалась наличием определенного, присущего ей стиля. Данный казус - это факт подчинения науки идеологическим установкам времени, по- 
скольку, как и другие стили, язык религиозной сферы отличается полным набором стилеобразующих признаков: особой формой общественного сознания и видом деятельности, специфическим целеполаганием речевого общения, набором самостоятельных жанров-текстотипов.

Выделение религиозного стиля, по мнению некоторых исследователей, требует специальной оговорки. Так, М.Н. Кожина полагает, что судьба религиозного стиля «на русской основе» достаточно сложна, а основания для его выделения ограниченны (своеобразное двуязычие в религиозной сфере и социальнополитические причины недавнего времени), поэтому вопрос о религиозном стиле требует специального изучения [Стилистический энциклопедический словарь русского языка, 2003 , с. 152]. Тем не менее исследователь отмечает, что в настоящее время религиозный стиль получает «права гражданства» и все более расширяет сферу применения. Л.П. Крысин, раньше других обратившийся к данной проблематике, ставит вопрос об особом статусе религиозной речевой деятельности, полагая, что «религиозно-проповеднический стиль должен занять подобающее ему место в функционально-стилистической парадигме современного русского литературного языка и получить соответствующее описание в литературе по стилистике» [Крысин, 1996, c. 138]. Ученый называет такой функциональный стиль религиозно-проповедническим, выделяя тем самым один из характерных жанров - проповедь. Вступая в дискуссию, О.А. Крылова называет данный стиль церковно-религиозным («термин церковно-религиозный предпочтительнее, так как указывает одновременно и на сферу общественной деятельности, в которой он функционирует, и на религиозную сферу общественного сознания, и на церковных деятелей как авторов соответствующих текстов» [Крылова, 2003, с. 63]) и полагает, что название религиозно-проповеднический тавтологично, оно сужает сферу функционирования стиля, ограничивая его одним жанром - проповедью. Соглашаясь с упреком О.А. Крыловой, отметим, что предлагаемый ею термин изерковно-религиозный стиль также тавтологичен: содержание понятия церковь входит в объем понятия религия.
Характеризуя церковно-религиозный стиль, О.А. Крылова рассматривает параметры речевых жанров, создающие системность церковно-религиозного стиля - содержание, коммуникативную цель, образ автора, характер адресата, систему языковых средств и особенности их организации. В результате автор приходит к выводу о том, что в современном русском литературном языке сформировалась определенная система языковых средств, которая включает в себя, помимо нейтральных, общекнижные языковые ресурсы, а также языковые единицы, имеющие газетно-публицистическую и церковно-религиозную окраску, но из которой полностью исключены сниженные языковые единицы; система средств обладает архаически-возвышенной, торжественной эмоционально-экспрессивной окраской; она выполняет информационносодержательную и эмоционально-воздействующую (в духе религиозной морали) функции; при этом создается образ автора как посредника между Богом и паствой. «Такую систему языковых средств есть все основания считать церковно-религиозным функциональным стилем современного русского литературного языка» [Крылова, 2001, с. 268].

В.А. Салимовский, также выделяющий церковно-религиозный стиль, предлагает интерпретировать его с позиций религиозного сознания, поскольку именно последнее воплощается в религиозных текстах, определяя их специфические черты [Кожина, Дускаева, Салимовский, 2008, с. 413]. Ученый выделяет конструктивный принцип религиозного стиля «особую содержательно-смысловую и собственно речевую организацию текстов, назначение которой состоит в содействии единению человеческой души с Богом» [Кожина, Дускаева, Салимовский, 2008, с. 415]. Указанный конструктивный принцип реализуется комплексом следующих стилевых черт: архаически-возвышенная тональность речи, символизация фактов и событий невидимого мира, религиозно-ориентированная оценочность речи, модальность достоверности сообщаемого [Кожина, Дускаева, Салимовский, 2008, с. 415].

Отмечая наряду с институциональной развитую личную форму духовной деятельности, Т.В. Матвеева предлагает называть стиль религиозным [Купина, Матвеева, 2013, с. 208], 
таким образом, возвращаясь к термину, который еще в 1992 г. предложил Й. Мистрик. Словацкий ученый указывал следующие особенности этого стиля: книжную риторичность, прослеживающуюся в библейских текстах, гомилетике и других составляющих литургии; диалогичность (разговор человека с Богом во время молитвы, а также священника с Богом и с верующими); использование неязыковых средств; предмет богослужения и эстетическое измерение религиозного акта. Религиозный стиль в трактовке Й. Мистрика характеризуется гимничностью, эмоциональностью, пафосом и помпезностью [Mistrik, 1992].

Принимая позицию, отраженную в работах Й. Мистрика и Т.В. Матвеевой, предлагаем использовать термин религиозный стиль как вполне достаточный для указания на соответствующую сферу деятельности и на форму общественного сознания.

\section{Специфика религиозного сознания как основа выделения

конструктивного принципа
религиозного стиля

Религиозный функциональный стиль русского литературного языка дополняет ставшую традиционной парадигму функциональных стилей, полностью соответствуя особым экстралингвистическим критериям. Религиозное сознание и соответствующая деятельность - главные экстралингвистические основания для выделения данного функционального стиля.

Общественное сознание, понимаемое как «категория для обозначения той социальной реальности, которая обусловливается в итоге общественным бытием и является в основном его отражением, духовным воспроизведением» [Краткий философский словарь, 2000, с. 216], с трудом поддается анализу, поскольку представляет собой обобщенный феномен духовной жизни общества: сложно «распутать живой клубок духовной жизни и проследить сплетение образующих его отдельных нитей - морально-философских мотивов и идей; здесь можно наперед рассчитывать лишь на приблизительную точность» [Франк, 1990, с. 81].

Выделяются следующие формы общественного сознания, соотносимые с существу- ющей системой функциональных стилей: политическое, правовое, нравственное, религиозное, эстетическое и научное сознание. Ocнованиями для данной классификации служат предмет и форма отражения, социальная функция, характер закономерностей развития, а также степень зависимости от общественного бытия. Общественное сознание имеет сложную структуру и разные уровни (обыденный и теоретический, концептуальный).

Остановимся на специфике религиозного сознания. Обыденное религиозное сознание составляют фрагментарные, разрозненные образы, представления, стереотипы, установки, настроения, привычки и традиции. На этом уровне главную роль играют эмоции - чувства и настроения, наглядно-образные формы сознания. Религиозное сознание на теоретическом, концептуальном, уровне - это целостная совокупность понятий, идей, принципов. Оно покоится на догматах веры (догмат - утверждение высшим религиозным институтом положения вероучения в качестве непреложно истинного), как правило, оформленных в канон, свод религиозных положений. В состав канона входит упорядоченное учение о Боге, мире, природе, обществе, человеке; ритуальные предписания. Еще один важный компонент религиозного сознания, который нельзя отнести ни к концептуальному уровню, ни к обыденному, - это религиозный опыт: медитация, экстаз, мистические видения, созерцание Бога и т. п.

Религиозное сознание кардинально отличается от остальных форм общественного сознания особенностями реализации функций. Философия выделяет следующие функции религии: иллюзорно-компенсаторную, так как религия дает человеку надежду на успокоение и моральное удовлетворение; мировоззренческую, так как создает свою картину мира; регулятивную, так как устанавливает свою систему норм и ценностей и тем самым регламентирует поведение человека; коммуникативную, так как способствует общению верующих людей [Философский энциклопедический словарь, 1983, с. 576-578]. Специфика реализации указанных выше функций религии обусловлена признанием существования двух миров: реального, земного и потустороннего, небесного, являющегося конечным смыслом 
бытия человека и определяющего его ценностно-смысловую ориентацию. «Религия всегда означает веру в реальность абсолютноценного, признание начала, в котором слиты воедино реальная сила бытия и идеальная правда духа» [Франк, 1990, с. 83].

Религия как сфера общественного сознания занимает особое место в ряду других выделяемых философским знанием сфер (наука, политика, искусство, право), так как формирует мировоззренческие установки субъекта. Она определяет не только особенности религиозной деятельности, но и особенности функционирования личности и общества в иных сферах человеческой деятельности. Религиозная картина мира отличается таким онтологическим принципом, как двоемирие, что детерминирует специфику собственно лингвистического конструктивного принципа религиозного стиля.

Функциональный стиль, помимо формы общественного сознания, определяется видом человеческой деятельности. Стиль обозначает, как пишет П. Гиро, «специфический способ действия» [Guiraud, 1963, p. 6]. Чешский лингвист К. Гаузенблас понимает стиль в самом общем смысле этого слова как определенный способ протекания целенаправленной деятельности, который предусматривает особенности и структуру этой деятельности [Гаузенблас, 1967, с. 70-71].

Религиозная деятельность отличается от других видов деятельности. Религиоведение предлагает следующую классификацию религиозной деятельности. Выделяется дихотомия: нерелигиозная / религиозная деятельность религиозных людей, групп, организаций. Нерелигиозная деятельность - это деятельность в экономической, производственной, политической, художественной, научной областях. Она может быть религиозно окрашена, но по объективному содержанию, предмету и результатам находится вне религии.

Собственно религиозная деятельность делится на внекультовую и культовую. Внекультовая осуществляется в духовной и практической сферах. Духовная сфера - это разработка религиозных концепций, систематизация и интерпретация догматов теологии, сочинение богословских произведений и т. д. Разновидностями практической внекультовой деятельности являются производство средств религиозного культа, миссионерство, преподавание богословских дисциплин в учебных заведениях, пропаганда религиозных взглядов.

Культовая религиозная деятельность это совокупность религиозных действий, определяемых каноном и направленных на служение Богу. Ее содержание обусловливается прототекстом. Воспроизведение событий прототекста во время богослужения является «высшей реальностью», во время которой происходит общение с трансцендентным миром. Человек имеет цель выше тварного мира, именно его соединение с Богом и есть его бытийное предназначение [Мейендорф, 1997, c. 162-163].

Основополагающей и специфической чертой религиозного сознания является стремление субъекта приблизиться к Богу, обрести единение с трансцендентной сущностью. В христианстве такое стремление трактуется как спасение, понимаемое как максимально возможное для каждого субъекта приближение к Богу после окончания земной жизни. Интенция спасения является глобальной и смыслообразующей, именно она формирует все остальные цели субъекта. Стремление к спасению предполагает различные степени ответственности как за себя, так и за других и зависит от социального статуса (священнослужитель отвечает за спасение прихожан, муж и отец - за спасение членов семьи), личного уровня духовного развития (любой человек, вне зависимости от социального статуса, отвечает за сохранение духовного равновесия находящихся рядом, отсюда максимальная степень ответственности за произносимые слова и совершаемые поступки).

Стремление субъекта к спасению, его постоянный ориентир на сакральные ценности определяют его поведение в земном мире. Интенция спасения формирует триаду мысль - слово - дело религиозно ориентированного человека в любой сфере деятельности, в частности, воплощенную в слове мысль, которая приводит к поступку.

Воссоединяя жизнь двух миров - земного, природно-социального, и трансцендентного, религия отличается своеобразием духовной деятельности: земной человек стремится к трансцендентному, с этим связано личное 
душеспасение: «Две вещи наполняют душу всегда новым и все более сильным удивлением и благоговением, чем чаще и продолжительнее мы размышляем о них, - это звездное небо надо мной и моральный закон во мне» [Кант, 2015, с. 92].

Таким образом, религиозное сознание, имеющее в своей основе идею двоемирия, и религиозная деятельность, главная интенция которой - спасение, являются мировоззренческими основаниями для выделения конструктивного принципа религиозного стиля на собственно лингвистических основаниях.

\section{Лингвистические основания выделения конструктивного принципа религиозного стиля}

Понятие «конструктивный принцип» введено в обиход функциональной стилистики В.Г. Костомаровым [Костомаров, 1970; 1971] и теоретически дополнено М.Н. Кожиной. Под конструктивным принципом понимается «ведущий принцип отбора языковых средств и их текстовой организации, обусловленный базовыми экстралингвистическими стилеобразующими факторами» [Стилистический энциклопедический словарь русского языка, 2003, с. 180]. Конструктивный принцип определяет основные стилевые черты, которые, в свою очередь, реализуются через набор лингвистических признаков [Стилистический энциклопедический словарь русского языка, 2003, с. 404].

Конструктивный принцип религиозного функционального стиля обусловлен особенностями религиозного сознания и религиозной деятельности. Онтологические (мировоззренческие) принципы двоемирия (объективно-статический аспект) и спасения (субъективно-динамический аспект) в проекции на текстосферу воплощаются в собственно лингвистическом конструктивном принципе прототекстуальности, предполагающем обязательную для каждого из последующих религиозных текстов опору на религиозный прототекст (для русского православия - текст Евангелия). Так обеспечивается преемственность и сохранность канонических мировоззренческих конструктов, в концентрированном виде содержащихся в прототекстах.

Под прототекстом мы понимаем целостный завершенный, закрытый канонический текст, передающий мысли Бога или пророков и содержащий в концентрированном виде ценностно-смысловые установки религиозной конфессии. В прототексте задаются установления и описываются образцы, которые формируют должное поведение человека. Прототекст является нерушимым идейным основанием и материально-языковым базисом всех производных текстов религиозного функционального стиля. Данная характеристика присваивается текстовому первоисточнику на том основании, что все последующие религиозные тексты воспроизводят и развивают исходный канонический образец.

Религиозные представления о мире земном и небесном, о месте и пути человека в нем в мировых религиях (буддизме, христианстве, исламе - в порядке возникновения) зафиксированы в соответствующих прототекстах. Такими прототекстами для традиционных конфессий являются следующие: в ведической религии «Веды», «Брахманы», «Упанишады»; в иудаизме «Танах», «Тора»; в зороастризме «Авеста»; в конфуцианстве «Ицзин (Книга перемен)», «Беседы и суждения»; в буддизме «Трипитака»; в даосизме «Дао дэ цзин»; в христианстве «Библия»; в исламе «Коран» [Мечковская, 1998, с. 118$231]$; каждый из них составляет формальносодержательный фундамент для всех текстов, создаваемых в пространстве одного религиозного стиля.

В прототексте задаются установки и описываются образцы, которые формируют должное поведение человека. Человек, живущий в религиозной системе координат, по принципам сакрального мира, мыслит и действует в соответствии с ними в любой иной сфере: в науке, политике, философии, искусстве. Любое событие, поступок, факт, слово, мысль в земном пространстве, a priori грешном, поверяется принципами, заданными в прототексте Священного Писания и Священного Предания.

Жизнь субъекта, находящегося в религиозной системе координат, последовательно протекает в двух мирах: земном (дольнем, профанном) и небесном (горнем, сакральном), причем жизнь в земном мире ориентирована на ценности, свойственные небесному миру. Ориентиром, задающим идеал и определяющим речемыслительную деятельность, явля- 
ется круг текстов Священного Писания и Священного Предания, где формулируются принципы мира небесного, зафиксирована речь Бога, обращенная к людям, а также событийный ряд, показывающий путь к спасению. Любой вид коммуникации в религиозной сфере генетически проистекает из прототекста Священного Писания и Священного Предания и опирается на них.

Прототекстуальность проявляется в преемственности способов текстуальной обработки выдвигаемых концептов мировоззрения. Прототекст содержит жанровые образцы, исчерпывающие потребности субъектов религиозной деятельности применительно к основным ситуациям религиозной коммуникации. Канонизированные инвариантные жанровые модели, представленные в совокупном прототексте Евангелия, предлагается назвать протожанрами.

Анализ текста Евангелия в сопоставлении с открытой текстосферой современного религиозного стиля позволяет выделить в качестве эталонных три протожанра: проповедь (основной прототекст в составе Евангелия Нагорная проповедь), молитву (основной прототекст в составе Евангелия - Отче наш), и житие (прототекст Евангелия в целом как жизнеописания Иисуса Христа). Самостоятельность данных протожанров определяется уже анализом прагматической рамки, позволяющим установить направление религиозной коммуникации на основе принадлежности адресанта и адресата речи сакральному или профанному миру.

Протожанр проповеди отличается спецификой позиции адресанта. Иисус Христос-Бог, временно находящийся в земном, профанном мире. Разъясняя свое учение, Он произносит Нагорную проповедь, текст которой является целостной экспликацией протожанра, задающей образцовую жанровую модель. Любой последующей проповеди свойственна модифицированная схема коммуникации, когда адресантом текста выступает проповедник как представитель сакрального мира, от лица Церкви осуществляющий главную цель данного жанра: научить адресата, разъяснить Божественную истину представителям мира профанного. Типовая содержательная структура проповеди включает в себя три компо- нента: утверждение, разъяснение и предписание (вариант - назидание). Композиция отражает приведенную последовательность. Модификация данной структуры связана с использованием «протопрототекста», когда в качестве исходного утверждения проповеди используется положение из Ветхого Завета, а в роли объяснения используется логически развивающее его положение из Нового Завета. В Евангелии, кроме Нагорной проповеди, демонстрируются различные виды проповеди и способы предъявления убеждающего материала различным типам аудитории: по уровню осведомленности, по уровню доброжелательности по отношению к оратору, по объему текста. Эти варианты могут рассматриваться как прототексты субжанровых разновидностей проповеди.

Протожанр молитвы эксплицирован в Евангелии в виде текстов Отче наш, молитвы мытаря, Моления о чаше и других текстов, созданных по единой модели, которая модифицируется в зависимости от коммуникативной ситуации. Единство обеспечивается комплексом обязательных содержательных компонентов, выстроенных в типичную композиционную последовательность. На лингвостилистической основе выделены прагматические компоненты жанра (целенаправленные речевые действия отправителя текста): обращение, просьба, характеристика, хвала. Каждое из этих действий формирует определенный содержательный фрагмент текста. Полное композиционное развертывание молитвы образует следующий ряд речевых действий отправителя: обращение $\rightarrow$ просьба $\rightarrow$ хвала $\rightarrow$ характеристика адресанта с указанием на его грешность $\rightarrow$ итог.

Особым образом реализован в Евангелии протожанр жития, возникший и развившийся в ходе распространения христианского вероучения после Воскресения Иисуса Христа. В прототексте Евангелия изображается жизнь и смерть Иисуса Христа, Бога в образе человека, явившегося в мир, чтобы исполнить Завет и спасти всех людей. Жизнеописание Иисуса Христа и задает протожанровую модель жития. Авторы Евангелия, используя хронологический композиционный ход, показывают образец поведения и пути спасения человека. Реализованная в прототексте модель жизнеописания Богочеловека служит 
текстовым ориентиром при создании любого житийного текста, поскольку его целью является демонстрация образцовой модели поведения христианина в земной жизни.

Триада рассмотренных протожанров с течением времени трансформируется в разветвленную жанровую систему. В современной жанровой системе каждый протожанр является содержательным и структурным основанием группы производных от него жанров - современных жанровых типов. Каждый жанровый тип на родовидовой основе делится на жанры и субжанры.

Каждый жанровый тип современного функционального религиозного стиля можно представить как понятийное поле. Ядро каждой жанровой подсистемы составляют жанры, используемые в богослужебной сфере, они максимально близки к протожанру в формально-содержательном отношении. Периферию жанровой подсистемы составляют жанры, функционирующие в небогослужебной сфере, они отличаются некоторой авторской свободой и в то же время сохраняют связь с каноническим прототекстом.

Жанровые подсистемы, генетически восходящие к протожанрам молитвы, проповеди и жития, имеют общую коммуникативную рамку (субъекты религиозной коммуникации принадлежат к разным мирам; общение характеризуется благоговейной тональностью по отношению к Богу и другим представителям сакрального мира), однако различаются по направлению коммуникации и способу текстуальной обработки содержания.

Ядро жанрового типа проповеди включает в себя богослужебные жанры церковной проповеди, послания, беседы; церковная проповедь характеризуется делением на множество субжанров (миссионерская, катехизическая, экзегетическая и др. проповеди). На периферии функционируют такие жанры, как статья, беседа в чате, заметки о путешествиях (современный вариант жанра хождения). Коммуникативным основанием для выделения жанров в пределах жанрового типа проповеди служат целеполагание адресанта и тип адресата. Цель адресанта - сообщить Истину, убедить адресата принять Истину - реализуется в убеждающем тексте проповеди в зависимости от типа аудитории: учитывается уровень воцерковленности, образованности, доброжелательности паствы.

Для проповеди как типа текста характерно доминирование категории темы. Данная текстовая категория в пределах своего текстотипа получает жесткую дифференциацию (с различением темы духовной, предметной и ситуативной, на более низком уровне абстракции - с делением предметной темы на сакрально-предметную и профанно-предметную), в результате чего определяется тематическая иерархия с главенством духовной темы. Доминирование категории темы выражается в ее развернутой текстуальной проработке и прямом влиянии на композицию проповеди. Жанровый тип характеризуется устойчивыми схемами композиционного развития темы.

Ядро жанрового типа молитвы включает в себя богослужебные жанры: собственно молитва, канон, кондак, акафист, величание, тропарь и др., периферию составляют авторская неканоническая молитва, авторский неканонический акафист, заговор, художественные произведения - стихотворные молитвы. Основанием для выделения жанров внутри жанрового типа служит критерий интенциональности адресанта, доминирование той или иной интенции и группировка интенций из числа свойственных религиозному стилю является жанрообразующим фактором. Так, интенция хвалы и благодарности формирует жанр акафиста, интенция просьбы и покаяния - жанр канона. Собственно церковная молитва является базовым жанром и может включать в себя все интенции: просьбы, покаяния, хвалы, благодарности в различном соотношении. Композиционное структурирование текста молитвы определяется интенцией и мотивированными ею речевыми действиями коммуниканта.

Современный жанровый тип жития представляет собой целостное образование. Его источником является Евангелие в целом, жанр жития опирается не на текст, включенный в Евангелие, а на текстовую модель жизнеописания Иисуса Христа, данную в Евангелии. По этому образу и подобию строятся все последующие житийные тексты, сохраняющие прототекстуальное композиционно-тематическое решение и организацию хронотопа. Даже авторская интенция жизнеописания не меняет- 
ся существенно в связи со сменой субъекта текста: житие тоже отражает идеал достижения главной цели христианина - оБожения. В рамках данного жанра особую значимость приобретает категория хронотопа, непосредственно связанная с композиционным решением текста.

В богослужебной сфере данный жанр делится на субжанры, выделяемые на экстралингвистических основаниях: по лику святости. Периферию жанра жития составляют небогослужебные жанры биографии, автобиографии, жизнеописания, романа, повести, рассказа, при условии, что в последних эксплицирована ведущая цель данного жанра - показать образец поведения человека, способствующий достижению спасения.

\section{Выводы}

Онтологическим основанием религиозного стиля является двоемирие, главная интенция религиозного текстопорождения - спасение. Философское понимание двоемирия как отличительного признака религиозного сознания реализуется в религиозном стиле через прототекстуальность, которая, представляя собой конструктивный принцип религиозного функционального стиля, проявляется в константной связи всех текстов и жанров-текстотипов с религиозным прототекстуальным источником. Так обеспечивается преемственность и сохранность канонических мировоззренческих конструктов, в концентрированном виде содержащихся в прототипическом текстовом источнике.

Все три подсистемы религиозного стиля русского языка (молитва, проповедь и житие) прошли процесс развития, каждая на своей прототекстовой основе. Они продолжают свое активное существование в виде жанровых групп современного религиозного стиля. Названные жанровые типы сохраняют центральное местоположение в жанровой системе религиозного функционального стиля. Наряду с этим активно формируется периферия стиля, образуемая жанрами, не выполняющими собственно богослужебных функций и находящимися на пересечении с другими функциональными стилями. Периферию образуют создаваемые с максимальной для религиоз- ного православного сознания степенью свободы тексты, относящиеся к различным видам религиозной деятельности, обеспечивающим существование Церкви как социального института общества и ее миссионерскую деятельность. Тем не менее и для периферийных текстов в разной степени эксплицированности характерна опора на прототекст.

Идейная и содержательная близость к прототексту, следование заданным в нем канонам определяет полевую структуру жанров религиозного стиля, их ядерную или периферийную принадлежность.

Прототекстуальность проявляется также в преемственности способов текстуальной обработки выдвигаемых концептов мировоззрения.

\section{ПРИМЕЧАНИЕ}

${ }^{1}$ Исследование поддержано программой 211 Правительства Российской Федерации, соглашение № 02.A03.21.0006. Supported by Act 211 Government of the Russian Federation, agreement № 02.A03.21.0006.

Исследование выполнено при финансовой поддержке РФФИ в рамках научного проекта № 18-012-00382А «Речевой быт семьи: аксиологическая реальность и методы исследования (на материале живой речи уральского города)».

\section{СПИСОК ЛИТЕРАТУРЫ}

Бобырева Е. В., 2013. Сферы функционирования и особенности религиозного дискурса // Мир науки, культуры, образования. № 5 (42). С. $296-298$.

Бугаева И. В., 2016. Лингвотеология как новое направление лингвистических исследований // Научное наследие Б.Н. Головина в свете актуальных проблем современного языкознания (к 100-летию со дня рождения Б.Н. Головина) : сб. ст. по материалам Междунар. науч. конф. (28-30 сент. 2016 г.). Нижний Новгород : Деком. С. 87-92.

Гадомский А. К., 2009. О филологических и нефилологических направлениях изучения религиозного языка в русской и польской теолингвистике // Ученые записки Таврического национального университета им. В.И. Вернадского. Т. 22 (61), № 1. С. 204-214.

Гаузенблас К., 1967. К уточнению понятия «стиль» и к вопросу об объеме стилистического исследования // Вопросы языкознания. № 5. C. 69-75. 
Кант И., 2015. Критика практического разума. М. : Эксмо. $92 \mathrm{c}$.

Кожина М. Н., 1977. Стилистика русского языка. М. : Просвещение. 223 с.

Кожина М. Н., Дускаева Л. Р., Салимовский В. А., 2008. Стилистика русского языка. М. : Флинта : Наука. 464 с.

Костомаров В. Г., 1970. Тезисы возможной концепции функциональных стилей // Из опыта преподавания русского языка нерусским. Вып. 5. М. : Высшая школа. С. 116-132.

Костомаров В. Г., 1971. Русский язык на газетной полосе. М. : Изд-во МГУ. 267 с.

Краткий философский словарь, 2000. Под ред. А. П. Алексеева. М. : Проспект. 396 с.

Крылова О. А., 2001. Можно ли считать церковнорелигиозный стиль современного русского литературного языка разновидностью газетно-публицистического? // Стереотипность и творчество в тексте : межвуз. сб. научн. тр. Пермь : Перм. ун-т. С. 259-269.

Крылова О. А., 2003. Портрет речевого жанра церковно-религиозного послания // Русский язык в России на рубеже 20-21 вв. : материалы междунар. науч. конф. (5-6 мая 2003 г.). Сaмара : Изд-во СамГПУ. С. 63-65.

Крысин Л. П., 1996. Религиозно-проповеднический стиль и его место в функционально-стилистической парадигме современного русского литературного языка // Поэтика. Стилистика. Язык и культура: памяти Т.Г. Винокур. М. : Наука. С. 135-138.

Купина Н. А., Матвеева Т. В., 2013. Стилистика современного русского языка. М. : Юрайт. 415 с.

Мейендорф И. (прот.), 1997. Православие в современном мире. М. : Свято-Тихон. богослов. ин-т. 230 с.

Мечковская Н. Б., 1998. Язык и религия. М. : Агентство ФАИР. 352 с.

Прохватилова О. А., 1999. Православная проповедь и молитва как феномен современной звучащей речи. Волгоград : Изд-во ВолГУ. 364 с.

Салимовский В. А., Суслова К. С., 2005. Экспликация догмата как жанра догматической проповеди // Жанры речи. Вып. 4. Саратов : Колледж. С. 280-292.

Стилистический энциклопедический словарь русского языка, 2003. Под ред. М. Н. Кожиной. М. : Большая Российская энциклопедия. 696 с.

Философский энциклопедический словарь, 1983. Сост.: Л. Ф. Ильичев, П. Н. Федосеев, С. М. Ковалев, В. Г. Панов М. : Советская энциклопедия. $840 \mathrm{c.}$

Франк С. Л., 1990. Сочинения. М. : Правда. 608 с. Guiraud P., 1963. La stilistique (Coll. «Que sais-je?»). Paris. : PUF. 120 p.
Mistrik J., 1992. Religiózty štýl // Stylistika. I. Opole : Uniwersytet. Opolski. S. 82-89.

\section{REFERENCES}

Bobyreva E.V., 2013. Areas of functioning and pecularities of religious discourse. Mir nauki, kultury, obrazovaniya [The World of Science, Culture and Education], no. 5 (42), pp. 296-298.

Bugaeva I.V., 2016. Linguistic theology as a new area of language studies. Nauchnoe nasledie B.N. Golovina $v$ svete aktualnykh problem sovremennogo yazykoznaniya (k 100-letiyu so dnya rozhdeniya B.N. Golovina): sbornik statey po materialam Mezhdunarodnoy nauchnoy konferentsii (28-30 sentyabrya 2016). Nizhniy Novgorod, Dekom Publ., 2016, pp. 87-92.

Gadomskiy A.K., 2009. On philological and nonphilological areas of religious language study in Russian and Polish theolinguistics. Uchenye zapiski Tavricheskogo natsionalnogo universiteta im. V.I. Vernadskogo [Scientific Notes of Taurida National V.I. Vernadsky University], vol. 22 (61), no. 1, pp. 204-214.

Gauzenblas K., 1967. On the concept of 'style' and on the scale of stylistic research. Voprosy yazykoznaniya [Topics in the Study of Language], no. 5, pp. 69-75.

Kant I., 2015. Critique of Practical Reason. Moscow, Eksmo Publ. 92 p.

Kozhina M.N., 1977. Stylistics of the Russian language. Moscow, Prosveshchenie Publ. 223 p.

Kozhina M.N., Duskaeva L.R., Salimovskiy V.A., 2008. Stylistics of the Russian language. Moscow, Flinta Publ.; Nauka Publ. 464 p.

Kostomarov V.G., 1970. Theses of possible conception of functional styles. Iz opyta prepodavaniya russkogo yazyka nerusskim. Vyp. 5. Moscow, Vysshaya shkola Publ., pp. 116-132.

Kostomarov V.G., 1971. The Russian language on newspaper pages. Moscow, Izd-vo MGU. 267 p.

Alekseev A.P., (ed.) 2000. Brief dictionary of philosophy. Moscow, Prospekt Publ. 396 p.

Krylova O.A., 2001. Can a church and religious style of the modern Russian literary language be considered as a type of a newspaper style? Stereotipnost i tvorchestvo v tekste: mezhvuz. sb. nauchn. tr. Perm, Perm. un-t Publ., pp. 259-269.

Krylova O.A., 2003. A speech genre of church and religious message. Russkiy yazyk $v$ Rossii na rubezhe $X X-X X I$ vv.: materialy mezhdunarodnoy nauchnoy konferentsii (5-6 maya 2003 g.). Samara, Izd-vo SamGPU, pp. 63-65.

Krysin L.P., 1996. Religious and sermon style and its role in the functional and stylistic paradigm of 
the modern Russian literary language. Poetika. Stilistika. Yazyk i kultura: Pamyati T.G. Vinokur. Moscow, Nauka Publ., pp. 135-138.

Kupina N.A., Matveeva T.V., 2013. Stylistics of the modern Russian language. Moscow, Yurayt Publ. 415 p.

Meyendorf I. (archpriest), 1997. Orthodoxy in the modern world. Moscow, Svyato-Tikhonovskiy Bogoslovskiy institut Publ. 230 p.

Mechkovskaya N.B., 1998. Language and religion. Moscow, Agentstvo FAIR. 352 p.

Prokhvatilova O.A., 1999. Orthodox sermon and prayer as a phenomenon of modern speech. Volgograd, Izd-vo VolGU. 364 p.

Salimovskiy V.A., Suslova K.S., 2005. Explication of dogma as a genre of dogmatic sermon. Zhanry rechi. Vyp. 4 [Speech Genres. Iss. 4]. Saratov, Kolledzh Publ., pp. 280-292.

Kozhina M.N. (ed.), 2003. Encyclopedic Russianlanguage dictionary of stylistics. Moscow, Bolshaya Rossiyskaya entsiklopediya Publ. $696 \mathrm{p}$.

Ilyichev L.F., Fedoseev P.N., Kovalev S.M., Panov V.G., 1983. Encyclopedic dictionary of philosophy. Moscow, Sovetskaya entsiklopediya Publ., 1983. $840 \mathrm{p}$.

Frank S.L., 1990. Works. Moscow, Pravda Publ. 608 p. Guiraud P., 1963. La stilistique (Coll. “Que sais-je?”). Paris, PUF. 120 p.

Mistrik J., 1992. Religiózty štýl. Stylistyka. I. Opole, Uniwersytet Opolski, pp. 82-89.

\section{Information about the Author}

Tatyana V. Itskovich, Doctor of Sciences (Philology), Associate Professor, Professor of Department of Russian Language, General Linguistics and Speech Communication, Ural Federal University named after the First President of Russia B.N. Eltsin, Lenina St., 51, 620000 Ekaterinburg, Russia, Tatiana.Itckovich@urfu.ru, https://orcid.org/0000-0002-5841-2943

\section{Информация об авторе}

Татьяна Викторовна Ицкович, доктор филологических наук, доцент, профессор кафедры русского языка, общего языкознания и речевой коммуникации, Уральский федеральный университет им. первого Президента России Б.Н. Ельцина, ул. Ленина, 51, 620000 г. Екатеринбург, Россия, Tatiana.Itckovich@urfu.ru, https://orcid.org/0000-0002-5841-2943 